\title{
A Review of the Antiobesity and Hypolipidemic Aspects of Caraway (Carum carvi L.)
}

\author{
Sherafatmanesh $\mathrm{S}^{1}$ and Ekramzadeh $\mathrm{M}^{2 *}$ \\ Student Research Committee, School of Nutrition and Food Sciences, Shiraz University of Medical Sciences, Shiraz, Iran \\ Department of Clinical Nutrition, School of Nutrition and Food Sciences, Shiraz University of Medical Sciences, Shiraz, Iran \\ Submission: May 16, 2017; Published: June 12, 2017
}

*Corresponding author: Ekramzadeh M, Nutrition Research Center, Department of Clinical Nutrition, School of Nutrition and Food Sciences, Shiraz University of Medical Sciences, Shiraz, Iran, Tel: +98-71-37251004; Email: mekramzade@gmail.com

\begin{abstract}
Medicinal plants play a key role in treatment of various diseases. Following the present global obesity trend and its pivotal role in several health problems, the aim of this review is to highlight the Antiobesity and Hypolipidemic effects of Caraway (Carum carvi L.) as a natural therapy for weight and blood lipid management.
\end{abstract}

Keywords: Obesity; Caraway; Weight; Blood lipid

\section{Mini Review}

Today, obesity recognized as one of the foremost causes of death in human society $[1,2]$. Worldwide report of International Obesity Taskforce in 2010, showed that about 1.6 billion adults have excess body weight with body mass index (BMI) greater than $25 \mathrm{~kg} / \mathrm{m}^{2}[1,3]$. More, according to the World Health Organization (WHO), Since 1980, "globosity" has almost doubled in human population [1,3]. Obesity and hyperlipidemia are the common denominators of chronic diseases such as cardiovascular disease, diabetes, musculoskeletal disorders and cancer which results in weakened psychosocial dimensions and extensive health care costs for the society [2-4]. Therefore, management of obesity and hyperlipidemia is a highly community health requirement. Despite all several modern approaches, including pharmaceutical products, bariatric surgery and several different dietary supplements, there is still an increasing demand for traditional, accessible and affordable natural treatments with less adverse outcomes such as medicinal plants for weight and blood lipid management [1,3-5]. Caraway (Carum carvi L.), from the Apiaceae family, is one of the common well-known herbs, naturally found in Northern and Central Europe, Siberia, Turkey, Iran, India and North Africa [1,3,4]. The major phytochemical and bioactive metabolites in caraway are carvone (mostly), limonene, thymol, carveol, carvacrol, linalool, estragol and anethole $[4,6,7]$. Tolerability, hepatoprotective influence and safe usage of caraway have been approved by several studies $[8,9]$. Caraway as a subset of antiobesity plants is still being used for treating obesity in traditional medicine. Several animal and human studies have suggested the favorable antiobesity and hypolipidemic effects of caraway usage $[3,8,10]$. One clinical trial study on 70 overweight and obese women revealed significant decreases in body weight, BMI, body fat percentage and waist-tohip ratio after consuming $30 \mathrm{ml} /$ day caraway extract for 3 month [3]. Also in another study consumption of $30 \mathrm{ml} /$ day caraway extract for 90 days showed a significant decrease in appetite and anthropometric indicators [1]. Bioactive metabolites in caraway with antioxidant activity such as, carvone, limonene, carveol, thymol and carvacrol could play an important role in reducing body weight [8]. Caraway increases secretion of hormones, affecting the sense of satiety such as leptin and cholecystokinin (CCK) which in turn results in delayed gastric emptying, loss of appetite and decrease in body fat [2]. It also stimulates apoptosis in preadipocytes, as well as lipolysis in fat droplets [3]. In 2016, an animal study was conducted to evaluate the effects of caraway aqueous extract (CAE) at doses of 60 and $90 \mathrm{mg} / \mathrm{kg} /$ day on levels of CCK for 8 weeks. Results of this study demonstrated an increase in levels of CCK and also a reduction in TG (triglycerides), LDL (low density lipoproteins) and total cholesterol concentrations in control and intervention groups [2].

Similarly, referring to hypolipidemic effects of caraway, one animal study showed significant hypolipidemic effects of caraway in both normal and streptozotocin-diabetic rats [11]. Another animal study which was based on comparing the lipid 
lowering effects of CAE and simvastatin in hyperlipidemic rats showed the reduced levels of serum TG, LDL and total cholesterol in intervention group compared to the control group and also higher effectiveness of CAE compared to simvastatin was reported on serum lipid levels [4].

As mentioned above, the caraway antioxidant potential components also can play an important role in reducing hyperlipidemia [6]. Furthermore, caraway cholesterol lowering effects could be related to the reductions in HMG-CoA reductase (3-hydroxy-3-methyl-glutaryl-coenzyme A reductase) activity (the key enzyme of cholesterol biosynthesis) and NADPH (nicotinamide adenine dinucleotide phosphate) concentration (necessary for fatty acids and cholesterol synthesis) [7]. Moreover, it has been found that caraway can modify the metabolism of lipoproteins through the following mechanisms: [7].

A. Higher LDL cholesterol uptake through up regulation of its receptors

B. Increasing the activity of the lecithin-cholesterol acyltransferase (LCAT), the enzyme which play an important role in regulation of blood lipids

C. Facilitating the rapid catabolism of LDL cholesterol in the body

\section{Conclusion}

This paper summarized the research efforts to determine the importance of caraway usage as one of the promising safety profile antiobesity and lipid lowering herbs. It can be concluded that caraway and its metabolites may possess a number of different functions, including suppressing appetite, increasing lipolysis, improving body composition by lowering BMI, body weight, body fat, and also reducing cholesterol biosynthesis and improving metabolism of lipoproteins. Therefore, caraway could be recommended as an encouraging factor for safe usage as a traditional antiobesity and hypolipidemic medicine.

\section{References}

1. Kazemipoor M, Hamzah S, Hajifaraji M, Radzi CW, Cordell GA (2016) Slimming and Appetite-Suppressing Effects of Caraway Aqueous
Extract as a Natural Therapy in Physically Active Women. Phytother Res 30(6): 981-987.

2. Pourahmadi M, Jahromi H, Rooeintan Y (2016) The effect of aqueous extract of caraway seed (Carum carvi) on Cholecystokinin hormone in male rat. Journal of Fundamental and Applied Sciences 8(4): 20232035.

3. Kazemipoor M, Hajifaraji M, Haerian BS, Mosaddegh MH, Cordell GA, et al. (2013) Antiobesity effect of caraway extract on overweight and obese women: a randomized, triple-blind, placebo-controlled clinical trial. Evidence-Based Complementary and Alternative Medicine, pp. 8.

4. Saghir MR, Sadiq S, Nayak S, Tahir MU (2012) Hypolipidemic effect of aqueous extract of Carum carvi (black Zeera) seeds in diet induced hyperlipidemic rats. Pak J Pharm Sci 25(2): 333-337.

5. Jouad H, Haloui M, Rhiouani H, El Hilaly J, Eddouks M (2001) Ethnobotanical survey of medicinal plants used for the treatment of diabetes, cardiac and renal diseases in the North centre region of Morocco (Fez-Boulemane). J Ethnopharmacol 77(2-3):175-182.

6. Agrahari P, Singh DK (2014) A review on the pharmacological aspects of Carum carvi. Journal of Biology and earth sciences 4(1):1-13.

7. Haidari F, Seyed-Sadjadi N, Taha-Jalali M, Mohammed-Shahi M (2011) the effect of oral administration of Carum carvi on weight, serum glucose, and lipid profile in streptozotocin-induced diabetic rats. Saudi Med J 32(7): 695-700.

8. Kazemipoor M, Radzi CW, Hajifaraji M, Cordell GA (2014) Preliminary Safety Evaluation and Biochemical Efficacy of a Carum carvi Extract: Results from a Randomized, Triple-Blind, and Placebo-Controlled Clinical Trial. Phytother Res 28(10): 1456-1460.

9. Samojlik I, Lakić N, Mimica-Dukić N, Đaković-Švajcer K, Božin B (2010) Antioxidant and hepatoprotective potential of essential oils of coriander (Coriandrum sativum L.) and caraway (Carum carvi L.) (Apiaceae). J Agric Food Chem 58(15): 8848-8853.

10. Kamaleeswari M, Nalini N (2006) Dose-response efficacy of caraway (Carum carvi L.) on tissue lipid per oxidation and antioxidant profile in rat colon carcinogenesis. Journal of pharmacy and pharmacology 58(8):1121-1130.

11. Lemhadri A, Hajji L, Michel J-B, Eddouks M (2006) Cholesterol and triglycerides lowering activities of caraway fruits in normal and streptozotocin diabetic rats. J Ethnopharmacol 106(3): 321-326.

This work is licensed under Creative

Commons Attribution 4.0 Licens

DOI: 10.19080/MABB.2017.01.555564
Your next submission with Juniper Publishers will reach you the below assets

- Quality Editorial service

- Swift Peer Review

- Reprints availability

- E-prints Service

- Manuscript Podcast for convenient understanding

- Global attainment for your research

- Manuscript accessibility in different formats

( Pdf, E-pub, Full Text, Audio)

- Unceasing customer service

Track the below URL for one-step submission https://juniperpublishers.com/online-submission.php 